\title{
SNHG5 Gene
}

National Cancer Institute

\section{Source}

National Cancer Institute. SNHG5 Gene. NCI Thesaurus. Code C132180.

This gene plays a role in small nucleolar RNA synthesis. 